IdeAs

Idées d'Amériques

13 | 2019

La photographie documentaire contemporaine dans les Amériques

\title{
La fotografía documental contemporánea en las Américas
}

\section{Marion Gautreau y Jean Kempf}

Traductor. Marta Gómez

\section{(2) OpenEdition}

\section{Journals}

\section{Edición electrónica}

URL: http://journals.openedition.org/ideas/5554

DOI: 10.4000/ideas.5554

ISSN: 1950-5701

\section{Editor}

Institut des Amériques

\section{Referencia electrónica}

Marion Gautreau y Jean Kempf, "La fotografía documental contemporánea en las Américas », IdeAs [En línea], 13 | 2019, Publicado el 01 marzo 2019, consultado el 23 septiembre 2020. URL : http:// journals.openedition.org/ideas/5554; DOI : https://doi.org/10.4000/ideas.5554

Este documento fue generado automáticamente el 23 septiembre 2020

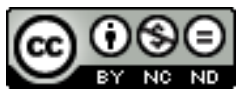

IdeAs - Idées d'Amériques est mis à disposition selon les termes de la licence Creative Commons Attribution - Pas d'Utilisation Commerciale - Pas de Modification 4.0 International. 


\title{
La fotografía documental contemporánea en las Américas
}

\author{
Marion Gautreau y Jean Kempf \\ Tradución : Marta Gómez
}

1 Es un hecho evidente, pero cabe recordarlo de nuevo, que los vínculos entre la fotografía y el mundo real son de una naturaleza específica en razón de la forma en que se produce la imagen. Es esta naturaleza particular la que muy pronto hizo de la fotografía una herramienta de revelación y aprendizaje sobre el mundo. Lo que poco a poco se ha dado en llamar «el documental» (existe un consenso general para situar la aparición del término en la década entre 1920-1930) se asienta en esta modalidad de la imagen fotográfica: se trata de utilizar la fotografía no como medio de expresión sino, por el contrario, como medio de exploración. No obstante, pese a su sencillez aparente, esta oposición es bastante más didáctica que real: no existen límites claros entre ambas áreas. Con todo, si bien hay muchas maneras de utilizar la fotografía en su vínculo con «lo real» -fotografía familiar, científica, de prensa, de identidad o policial, por poner algunos ejemplos- la naturaleza del documental es de otro orden. Pese a acercarse al fotoperiodismo, e incluso a la fotografía de prensa, tanto por los temas tratados como a veces por la forma plástica, no debe confundirse con él. El documental no se define ni por su estilo, como sugirió Olivier Lugon en una publicación histórica (Lugon 0., 2001), ni por el tema -lo extraordinario- como escribió Stuart Franklin (Franklin S., 2016: 9). Lo que lo caracteriza es, por un lado, un propósito, una intención, una posición de autor $\mathrm{y}$, por otro, una relación entre fotógrafo y sujeto que implica duración (aunque la temporalidad puede ser muy variable, yendo de algunos días a varios años e incluso décadas). Ambas modalidades implican también una especial atención dada a la forma en la que se difundirá el documental: formas propias de una narración compleja y gran vigilancia del fotógrafo respecto al uso que se hace o se hará de él. Todas estas condiciones pueden resumirse en una sola palabra: exigencia.

2 En la introducción de su último libro, Rebeca Monroy Nasr, historiadora de la fotografía mexicana desde hace más de treinta años y fotógrafa en sus comienzos, propone 
diferenciar entre fotoperiodismo y fotografía documental, dos prácticas que tienen en común un objetivo informativo pero cuyo modo de realización y usos difieren mucho:

La diferencia entre fotodocumentalismo y fotoperiodismo se establece a partir del uso social de la imagen y la intención con la que el fotógrafo toma esta imagen. Nos considerábamos fotógrafos documentales aquellos que captábamos el acontecimiento sin tener la certeza clara de la venta o la publicación del material. Trabajábamos con el deseo de dejar un testimonio visual del momento aunque éste solo se integrara a nuestro acervo personal, con la posibilidad de publicar posteriormente para realizar alguna exposición o edición de las imágenes en algún espacio público (Monroy Nasr R., 2017: 21).

Desde las grandes operaciones fotográficas que documentaron las expediciones al Oeste estadounidense (surveys) en el siglo xIX a los estudios urbanos sobre la vivienda precaria, la inmigración o el trabajo infantil a finales de siglo (Jacob Riis y Lewis Hine, por ejemplo), sin olvidar las imágenes de la Farm Security Administration de los años 1930, el enfoque documental gozaba ya de una larga historia cuando fue retomado y utilizado en los años 1920 y sobre todo entre 1930 y 1960 por parte de la prensa ilustrada bajo la forma de ensayo fotográfico o fotoensayo (photo essay) (Chouard G. et al. , 2014). Este término, muy poco utilizado en francés, retoma los códigos del ensayo literario: proponer una reflexión estructurada en torno a un tema claramente delimitado con el fin de despertar una toma de conciencia y, llegado el caso, abrir un debate sobre dicho tema. En esta línea precisamente, algunos fotoperiodistas adoptaron la práctica de la «doble cámara» en su profesión. La primera cámara sirve para hacer fotografías para periódicos y sitios web de información y produce imágenes que permiten ver lo mejor posible el contenido informativo de una situación. La segunda se utiliza para producir imágenes que encajan en series fotográficas, pensadas como tales y confeccionadas a más largo plazo. En esta línea se sitúa por ejemplo el fotoperiodista mexicano del Estado de Sinaloa Fernando Brito, quien a través de su trabajo documental denuncia la violencia vinculada a la guerra del narcotráfico y genera una conciencia social intrínsecamente ligada al documental.

4 Como sabemos, si bien la dominación de los modelos estadounidenses en el mundo de la fotografía desde finales de la Segunda Guerra Mundial es un hecho, y no solo en el campo de la fotografía artística (o plástica), incluso en la época actual de globalización de la imagen subsisten culturas visuales específicas -locales- que evocan o simplemente producen formas particulares de narrativa visual. Toda la dificultad $-\mathrm{y}$ todo el interés- de estudiar el documental fotográfico desde el continente americano en su conjunto reside en las diferencias de temporalidad en el desarrollo de esta práctica fotográfica según las regiones. Además, dado que la historia de la fotografía se ha escrito y difundido principalmente desde Europa y Estados Unidos, la exhumación de la historia de la fotografía documental en los países latinoamericanos a veces adquiere tintes de investigación arqueológica. Pocos relatos de historiadores describen la genealogía del documental chileno o brasileño, aunque el linaje existe claramente pese a la ausencia de trazo. Mientras, por el lado norteamericano, al menos desde el artículo de Beaumont Newhall de 1938 y la primera edición de su historia de la fotografía en 1949, el género es identificado, descrito, codificado y, en parte también, encuadrado y regulado ${ }^{1}$.

5 Por otra parte, no existe a priori convergencia entre las distintas fases de la fotografía documental en el norte y el sur del continente, como tampoco existe convergencia entre los «diferentes sures» del continente. Si bien las técnicas se difunden del mismo 
modo en todo el territorio de la Américas (aparición del similigrabado, generalización de la película flexible, introducción del color, transición a la fotografía digital), el impulso dado a la fotografía documental por parte de las instituciones y los distintos contextos políticos y sociales, así como por las posibilidades de producción, difiere considerablemente según los países. Las dictaduras del Cono Sur de los años 1970 y 1980 revelaron una necesidad imperiosa de ensayo fotográfico durante aquel periodo de represión y una imposibilidad material y física de llevarlo a cabo ${ }^{2}$. En cambio, en ese mismo periodo se desarrolló en México una intensa actividad documental que se originó con el fotoperiodismo, especialmente con los diarios Unomásuno y La Jornada, actividad de la que los fotógrafos acabarán emancipándose poco a poco para dedicarse a una fotografía de larga duración.

6 Por esta razón, para este número hemos optado por pedir a especialistas de la fotografía y la cultura de las Américas que reflexionen sobre las prácticas documentales específicas en el continente a fin de mostrar su diversidad, riqueza y complejidad, más que su convergencia.

7 Este número sobre prácticas documentales en las Américas (obviamente no es posible ser exhaustivos) está estructurado en torno a tres modalidades que en diverso grado están presentes en muchos proyectos documentales: la referencia científica o, por el contrario, ideológica, la forma artística como punto de acceso a la complejidad de lo real y, por último, la utilización del documental como herramienta de afirmación de una identidad o de una memoria reconquistada.

Combinando la observación de larga duración y la narración, el documental hace un uso natural y generalizado de las series, según formas más o menos estrictas pero que siempre dilatan la dimensión temporal para captar su significado en el proceso de transformación. Es el caso del meticuloso trabajo de inventario del fotógrafo chileno Camilo José Vergara, residente en Estados Unidos, donde ha reunido un metódico archivo urbanístico de guetos negros en el que Philippe Bazin (también fotógrafo) ve una máquina de guerra en el sentido deleuziano, «un medio de sacar [al gueto] del corsé en el que el ultraliberalismo violento lo ha encerrado desde hace décadas».

Igualmente comprometidas, aunque en las antípodas de la forma, las imágenes tomadas por el suizo Jean-Claude Wicky entre 1984 y 2001 en las minas bolivianas ilustran una fotografía humanista clásica -que con sus cuerpos retratados en ricas impresiones en blanco y negro recuerda las imágenes de W. Eugene Smith- y de una observación participativa. A través del trabajo de Wicky, poco conocido en Francia, Baptiste Lavat nos presenta lo que constituye la experiencia cotidiana de muchos documentalistas: el hecho de compartir vidas que ya no son enteramente las de sus protagonistas, pero que tampoco son completamente suyas, un "entre-dos" difícil que también experimentan los etnólogos, e incluso los sociólogos.

El lector que siga el orden del índice asistirá a un contraste brutal para descubrir después el espectáculo de la catástrofe, tal y como Danièle Méaux se refiere a las imágenes de las «ruinas de Detroit» de Yves Marchand y Romain Meffre, y al trabajo sofisticado y ambiguo de Joel Sternfeld sobre la High Line de Nueva York. Los vestigios de un poderoso pasado industrial despiertan hoy día un gran entusiasmo por lo que la autora llama con una bonita expresión «lo neopintoresco marginal», un área explotada por la fotografía posmoderna. Pese a presentar unas imágenes que estimulan la imaginación de los espacios y sugieren un "paisaje en devenir», con la documentación misma de la transformación paisajística del pasado industrial, Joel Sternfeld participa 
en la reapropiación chic por las clases sociales privilegiadas de antiguos espacios de trabajo y producción convertidos en lugares de ocio.

11 Esta dificultad para recrear la brutalidad y la exclusión que genera la ciudad moderna y, en general, para expresar lo real a secas (en su forma más cruda), es analizada por Gwen Cressman mediante la comparación de dos obras fotográficas bien diferentes -la de Martha Rosler y la de Jeff Wall- que sin embargo comparten la misma desconfianza ante la posibilidad de un acceso simple y directo a lo real a través de la fotografía. Plásticas y conceptuales, sus fotografías no dejan de analizar ese deseo de ver y esa resistencia del mundo a dejarse entender.

Mucho más concreta, la tercera parte de esta entrega ofrece tres recorridos diferentes que combinan el testimonio sobre una o varias realidades sociales, culturales o históricas con un intento de deconstruir estereotipos a través no solo de la fabricación de imágenes sino también de la integración en conjuntos discursivos, en dispositivos específicos. Morgana Herrera presenta el trabajo del fotógrafo peruano Musuk Nolte, que con sus series en blanco y negro se sitúa a contracorriente de las representaciones exóticas de la región amazónica. A través de la elección de sus personajes (más urbanos que rurales) y del tratamiento de las personas fotografiadas (en su día a día y en sus limitadas condiciones de vida), Nolte concede a los habitantes de la Amazonia peruana un lugar no etnográfico dentro de la escena visual internacional. Por su parte, Maude Oswald muestra cómo un inventario de símbolos funcionales (marcas hechas por los equipos de protección civil en los edificios abandonados de Nueva Orleans tras el paso del huracán Katrina) puede convertirse en Internet en una herramienta de construcción de la memoria a posteriori, dando sentido así a la acción «de vuelta» de los fotógrafos sobre lo real bajo la forma de una reapropiación. Dicha reapropiación está en el centro del proyecto que Aurélie Journée se propone estudiar: el de una fotógrafa amerindia cuyos retratos tratan de combinar una herencia ancestral con una modernidad que puede propiciar un discurso más pleno, sobre todo de las mujeres indígenas.

Como vemos, pese a que el recorrido propuesto es inevitablemente parcial, sí refleja en cambio las sutiles diferencias de una preocupación que atraviesa el documental: la de la emancipación.

\section{BIBLIOGRAFÍA}

Chouard, Géraldine, Kempf, Jean et Brunet, François, « La photographie "documentaire” américaine : nouvelles approches ", Transatlantica, vol. 2, 2014, http://journals.openedition.org/ transatlantica/7245, page consultée le 23 février 2019.

Franklin, Stuart, The Documentary Impulse, Londres, Phaidon, 2016.

Lugon, Olivier, Le style documentaire : d'August Sander à Walker Evans, 1920-1945, Paris, Macula, 2001. Meiselas, Susan (dir.), Chile from within, New York ; Londres, W.W. Norton \& Company, 1990. 
Monroy Nasr, Rebeca, Con el deseo en la piel. Un episodio de la fotografía documental a fines del siglo xx, Mexico, UAM-Xochimilco, 2017.

Newhall, Beaumont, « Documentary Approach to Photography », Parnassus, vol. 10, n 3, 1938, p. 2-6 [accessible sur JSTOR, http://www.jstor.org/stable/771747].

Newhall, Beaumont, The History of Photography from 1839 to the Present Day, New York, Museum of Modern Art, 1949. Traduction française en 1967.

\section{NOTAS}

1. Podemos aun así citar algunos nombres de historiadores de la fotografía latinoamericana que en la actualidad están reconstruyendo poco a poco esos relatos: Cora Gamarnik en Argentina, Boris Kossoy y Ana María Mauad en Brasil, Rebeca Monroy Nasr, John Mraz o Alberto del Castillo en México, por nombrar solo algunos.

2. Sobre este tema, véase Meiselas S., 1990.

\section{AUTORES}

\section{MARION GAUTREAU}

Profesora-investigadora del departamento de estudios hispánicos e hispanoamericanos de la Universidad Jean Jaurès de Toulouse. Historiadora de la fotografía latinoamericana y especialista en México. Sus trabajos se centran sobre todo en la fotografía de prensa y la fotografía documental en su articulación con el relato histórico nacional de los siglos xx y xxI. Es autora de la obra De la crónica al icono: la fotografía de la Revolución Mexicana en la prensa ilustrada capitalina (1910-1940) sobre la fotografía durante la Revolución Mexicana y trabaja actualmente sobre el fotoperiodismo mexicano desde 1968.

\section{JEAN KEMPF}

Profesor de civilización estadounidense en la Universidad Lumière-Lyon 2 y especialista de historia de la fotografía americana del siglo xx. Ha escrito sobre encargos institucionales, sobre los street photographers y sobre las prácticas documentales, y actualmente se interesa por la sociología de los círculos fotográficos contemporáneos. Asimismo, ha participado en la aventura de L'Amérique des images (Hazan, 2013) y ha publicado una Histoire culturelle des États-Unis (Belin, 2015). 